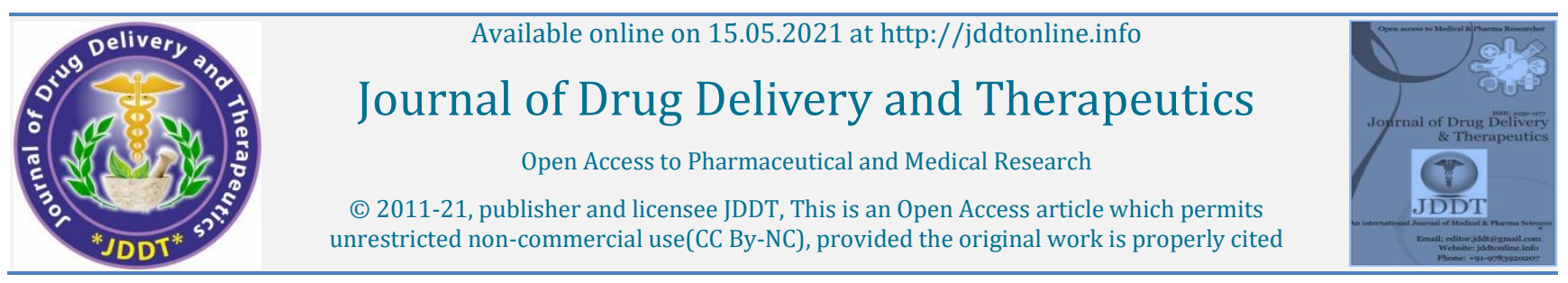

(C) 2011-21, publisher and licensee JDDT, This is an Open Access article which permits Open Access Full Text Article

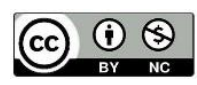

Research Article

\title{
In vitro efficacy of fungicides on mycelial growth and spore germination of Alternaria alternata and Mucor plumbeus
}

\author{
Jahangir Abdullah Koka*, Mohd Yaqub Bhat, Abdul Hamid Wani \\ Department of Botany, University of Kashmir, Hazratbal, Srinagar J. \& K. India
}

\section{Article Info}

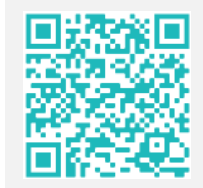

\section{Article History:}

Received 12 March 2021 Reviewed 16 April 2021 Accepted 21 April 2021 Published 15 May 2021

Cite this article as:

Koka JA, Bhat MY, Wani AH, In vitro efficacy of fungicides on mycelial growth and spore germination of Alternaria alternata and Mucor plumbeus, Journal of Drug Delivery and Therapeutics. 2021; 11(3):17-22

DOI: http://dx.doi.org/10.22270/jddt.v11i3.4692

\section{*Address for Correspondence:}

Jahangir Abdullah Koka, Department of Botany,

University of Kashmir, Hazratbal, Srinagar J. \& K. India

\section{Abstract}

Tomato fruits were infected by various pathogens especially fungal pathogens under storage conditions as well as in field conditions. It was revealed that tomato fruits are attacked by Alternaria alternata causing Alternaria rot of tomato and Mucor plumbeus causing Mucor rot of tomato. Antifungal activity of some fungicides was undertaken during the present study. Different concentrations of fungicides brought about significant reduction in the mycelial growth and spore germination of Alternaria alternata and Mucor plumbeus under in vitro conditions. Hexaconozole proved highly effective in inhibiting the mycelial growth and spore germination of Alternaria alternata followed by carbendazim and copper oxychloride respectively. However, the most effective fungicide in inhibiting the mycelial growth and spore germination of Mucor plumbeus was hexaconozole followed by carbendazim and copper oxychloride respectively.

Keywords: In vitro, fungicides, Alternaria alternata and Mucor plumbeus, mycelial growth, spore germination

\section{INTRODUCTION}

Tomato (Lycopersicon esculentum Mill.) is one of the most important vegetable crops in the world. It is considered as an important cash and industrial crop in many parts of the world ${ }^{1}$. Fungal rot is common, destructive and wide spread disease of all fruits and vegetables ${ }^{2}$. Several species of fungi, viz. Rhizopus sp., Mucor sp., Penicillium sp., Aspergillus sp., Colletotrichum sp., Botrytis sp., Monilinia sp., Alternaria sp., Phytophthora sp., have been reported to cause fungal rot diseases $^{3}$, 4 . Various chemical control measures have been tested and found effective in controlling plant diseases. ${ }^{5}$ highlighted some protective fungicides that have been found effective in controlling some plant diseases. The present study was carried out with the main objectives of identifying the fungal rot pathogens that cause decaying in tomatoes under storage conditions in Kashmir valley. The study was also undertaken for the management of identified fungal pathogens with some selected fungicides.

\section{MATERIALS \& METHODS}

To investigate the fungi which cause rotting of tomato fruits in Kashmir Valley, diseased fruits were collected from markets, godowns and storage houses of Kashmir Valley. These samples were either used immediately or stored at $10^{\circ} \mathrm{C}$ in the laboratory for different pathological studies. Small portions of rotted tissues were taken aseptically from the tomato fruits and transferred to potato dextrose agar (PDA) medium. Pure colony cultures were obtained by sub- culturing the fungal growth in separate Petri plates containing the same medium. The pathogens were identified by their morphological, reproductive and cultural characteristics $6,7,8,9$. For pathogenicity tests, pathogens were re-inoculated after isolation onto healthy tomato fruits ${ }^{10}$ and incubated at $25+2^{\circ} \mathrm{C}$ for 10 days. Identification of the disease and the pathogen was done following Koch's postulates. Different parameters such as symptoms caused by these fungi on the healthy tomato fruits, cultural characteristics of the pathogens and microscopic studies of the pathogens were studied.

In the present study an attempt was made to study the effect of some selected fungicides under in vitro conditions for the control of Alternaria rot of tomato caused by Alternaria alternata and Mucor rot caused by Mucor plumbeus.

\subsection{Preparation and evaluation of different fungicide concentrations}

Different concentrations ( $1000 \mathrm{ppm}, 500 \mathrm{ppm}, 250 \mathrm{ppm}$ and $125 \mathrm{ppm}$ ) of the fungicides copper oxychloride, carbendazim and hexaconozole were prepared in sterilized distilled water and evaluated for their effect on the mycelial growth of rot causing fungus, Alternaria alternata and Mucor plumbeus by food poisoning technique ${ }^{11}$. Appropriate concentration (1 $\mathrm{ml}$ ) of fungicide solution was mixed with autoclaved and cooled PDA just before pouring into Petri plates. The medium was then dispensed uniformly into $90 \mathrm{~mm}$ diameter Petri plates and inoculated with $5 \mathrm{~mm}$ mycelial disc of the 
pathogen from 10-days-old fungal culture. Three replicates were maintained for each concentration including control without any treatment. The Petri plates were incubated at $25 \pm 2{ }^{\circ} \mathrm{C}$ and observations of the mycelial growth of test fungus were recorded after 7 days of incubation. The percent inhibition in mycelial growth due to various fungicidal treatments at different concentrations was computed as formula

\section{Mycelial growth inhibition $(\%)=\{(\mathrm{dc}-\mathrm{dt}) / \mathrm{dc}\} \times 100$}

Where dc = average diameter of fungal colony in control, and $\mathrm{dt}=$ average diameter of fungal colony in treatment group.

For evaluating the effect of fungicides on spore germination, a spore suspension was prepared in sterilized distilled water. Spore suspension $(0.5 \mathrm{ml})$ was mixed with $0.5 \mathrm{ml}$ of the fungicides of different concentrations in a test tube and then shaken. In case of control $0.5 \mathrm{ml}$ of spore suspension was mixed with equal volume of distilled water. A drop of the mixture (about $0.1 \mathrm{ml}$ ) was then placed in a cavity slide and these were incubated for $25 \pm 2^{\circ} \mathrm{C}$ in a moist chamber created in $100 \mathrm{~mm}$ Petri plates by covering both sides of the Petri plate with moist filter paper to maintain humidity. Three replicates were maintained for each treatment including the control. The slides were examined after 24 hours by hand tally counts of different microscopic fields. Percent spore germination of each treatment was calculated by the formula given by 12 .

Percent spore germination $=($ No. of spores germinated $)$ Total no. of spores examined) $\times 100$

\section{RESULTS}

In the present study the casual pathogens infecting tomato fruits were identified as Alternaria alternata (Fr) Keissler and Mucor plumbeus Fisher resulting in Alternaria rot of tomato and Mucor rot of tomato. These two fungi were identified on the basis of symptoms caused by the fungus on tomato fruits and on the basis of cultural and microscopic characteristics. The symptoms of disease on tomato fruits are manifested by having dark, brown to black lesions which were upto 8-8.7 $\mathrm{mm}$ in diameter with white mycelium around the boundary. The lesion becomes darker and broadened in size (12.5-13.2 mm) with marked depression in the centre and elevated portion around the diameter. The lesions became slightly sunken after 7 days, which were of firm texture and 24.0-25.4 $\mathrm{mm}$ in diameter. The rot extended deep into the fruit rendering the tissues black, soft and watery. (Fig. a). The colony of Alternaria alternata appeared dark olive gray and finally black after ten days of inoculation on Potato Dextrose Agar (PDA) medium (Fig b). Microscopic studies revealed that the fungus is septate, hyaline with brown mycelia. The conidia are produced in chains of 2-20 at the tip of conidiophores which are branched or unbranched. The conidiophores are macronematous, mononematous, golden brown, septate, branched, walls smooth or slightly rough measuring 22.5-30.0 x 4.8-8.0 $\mu \mathrm{m}$ in diameter, flexous, geniculate; conidia are brown, variously shaped, usually obclavate, in long branched chains with short cylindrical beak upto 5 transverse septa, longitudinal and oblique septa also conspicuous, 19.2-28.8 x 8.0-14.4 $\mu \mathrm{m}$ in diameter (Fig c).
Fig a.

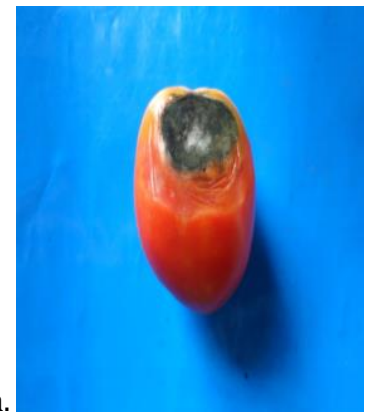

Fig. b.

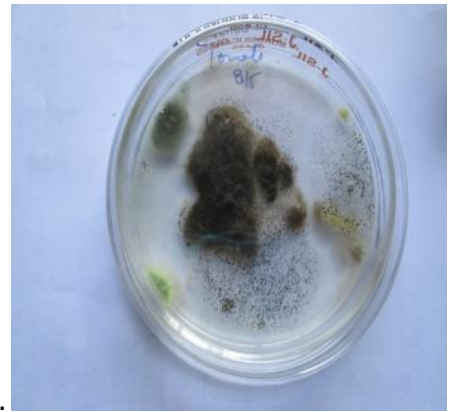

Fig. c

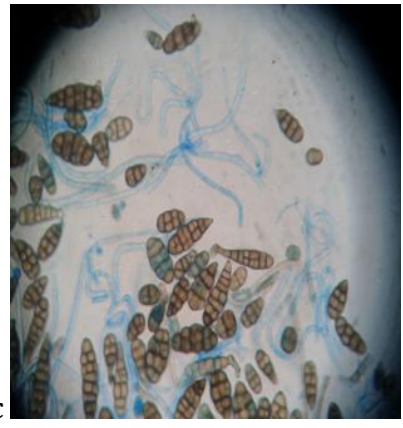

Figure a: Infected tomato fruit; Figure b: Culture of Alternaria alternata on PDA medium. Figure c: Alternaria alternata; Mycelium with conidia (400x)

The infected fruits are covered by gray, coarse and hairy mycelium that forms a mass of black sporangia at the tips. The rotten fruits have sour odor. The rot spreads by infection through wounds. The mycelium is white at first and then turns gray to black depending on sporulation (Fig. d). The fungus on Potato Dextrose Agar medium (PDA) produced colonies which are white at first and then turns black due to sporulation (Fig. e). Microscopic characteristics of the fungus revealed that the mycelium is non-septate and branched. Sporangiophore arises singly from the mycelium that terminate into sporangia. Sporangia are ovate or globose measuring about $80 \mu \mathrm{m}-200 \mu \mathrm{m}$ in diameter. Collumela is colourless and pear shaped. Spores are hyaline, ellipsoidal, 4 $\mu \mathrm{m}-6 \mu \mathrm{m} \times 7 \mu \mathrm{m}-11 \mu \mathrm{m}$ in diameter (Fig. f).
Fig d.

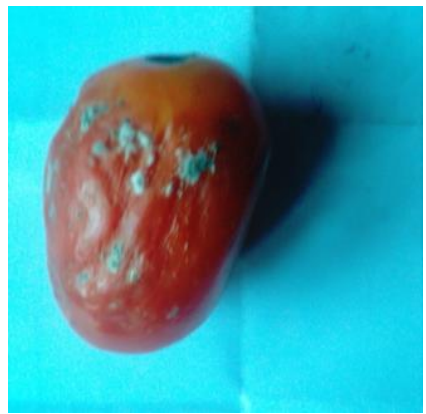

Fig e.

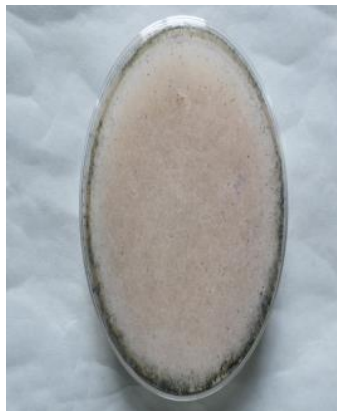

Fig $f$

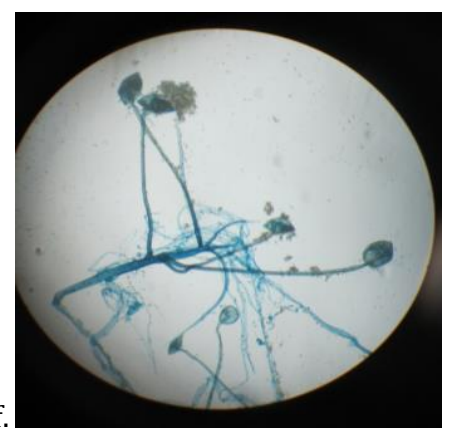

Figure d: Infected tomato fruit; Figure e: Culture of Mucor plumbeus on PDA medium. Figure f: M. plumbeus; Sporangiophores and sporangia (400x) 


\subsection{Effect of different concentration of fungicides on the mycelial growth of Alternaria alternata}

It was found from results (Table 1, Fig. 1) that all the fungicides, viz. copper oxychloride, carbendazim and hexaconozole at different concentrations (1000ppm, 500 ppm, 250ppm, 125ppm) brought about significant inhibition in the mycelial growth of Alternaria alternata as compared to control. However, the most effective fungicide in inhibiting the mycelial growth of Alternaria alternata was hexaconozole followed by carbendazim and copper oxychloride respectively. Hexaconozole at highest concentrations brought about maximum inhibition in mycelial growth followed by carbendazim and copper oxychloride at the same concentration. Other concentrations also caused significant inhibition in mycelial growth but to a lesser extent. In different concentrations of hexaconozole, the inhibition in mycelial growth varies from $100 \%-50.29 \%$ and in carbendazim it varies from $84.65 \%-48.31 \%$. Likewise, the inhibition in mycelial growth in copper oxychloride varies from $72.84 \%-39.98 \%$ in different concentrations of the fungicides respectively.
Effect of different concentrations of fungicides on the spore germination of Alternaria alternata

It was observed from results (Table 2, Fig. 2) that all the fungicides, viz. copper oxychloride, carbendazim and hexaconozole at different concentrations (1000ppm, 500 ppm, 250ppm, 125ppm) brought about considerable inhibition in the spore germination of Alternaria alternata as compared to control. Amongst the fungicides, the hexaconozole at highest concentration (1000ppm) was found most effective in inhibiting the germination of spores followed by carbendazim and copper oxychloride at same concentration. Other concentrations also brought about significant reduction in spore germination but to lesser extent. In hexaconozole the inhibition in spore germination varies from $63.36 \%-13.09 \%$ in different concentrations. In carbendazim, the reduction in spore germination varies from $69.71 \%$ - $16.55 \%$ and in copper oxychloride it varies from $71.60 \%-18.10 \%$ respectively in different concentrations.

Table 1: Effect of different concentrations of fungicides on the mycelial growth of Alternaria alternata

\begin{tabular}{|l|c|c|c|c|c|}
\hline \multirow{2}{*}{ Conc. } & \multicolumn{5}{|c|}{ Mycelial growth (mm) } \\
\cline { 2 - 6 } Treatment & $125 p p m$ & $250 p p m$ & $500 p p m$ & $1000 p p m$ & Control \\
\hline Copper oxychloride & $34.81 \pm 0.21^{\mathrm{b}}$ & $21.77 \pm 0.65^{\mathrm{c}}$ & $18.24 \pm 0.66^{\mathrm{d}}$ & $15.75 \pm 0.37^{\mathrm{e}}$ & $58.00 \pm 0.55^{\mathrm{a}}$ \\
& $(39.98)$ & $(62.46)$ & $(68.55)$ & $(72.84)$ & \\
\hline Carbendazim & $29.98 \pm 0.08^{\mathrm{b}}$ & $18.18 \pm 0.45^{\mathrm{c}}$ & $12.33 \pm 0.90^{\mathrm{d}}$ & $8.90 \pm 0.60^{\mathrm{e}}$ & $58.00 \pm 0.55^{\mathrm{a}}$ \\
& $(48.31)$ & $(68.65)$ & $(78.74)$ & $(84.65)$ & \\
\hline Hexaconozole & $28.83 \pm 0.39^{\mathrm{b}}$ & $12.62 \pm 0.50^{\mathrm{c}}$ & $6.44 \pm 0.74^{\mathrm{d}}$ & $0.00 \pm 0.00^{\mathrm{e}}$ & $58.00 \pm 0.55^{\mathrm{a}}$ \\
& $(50.29)$ & $(78.24)$ & $(88.89)$ & $(100)$ & \\
\hline
\end{tabular}

Each value is mean of 3 replicates \pm SD $\quad$ Figures in parenthesis is the mycelial growth inhibition (\%)
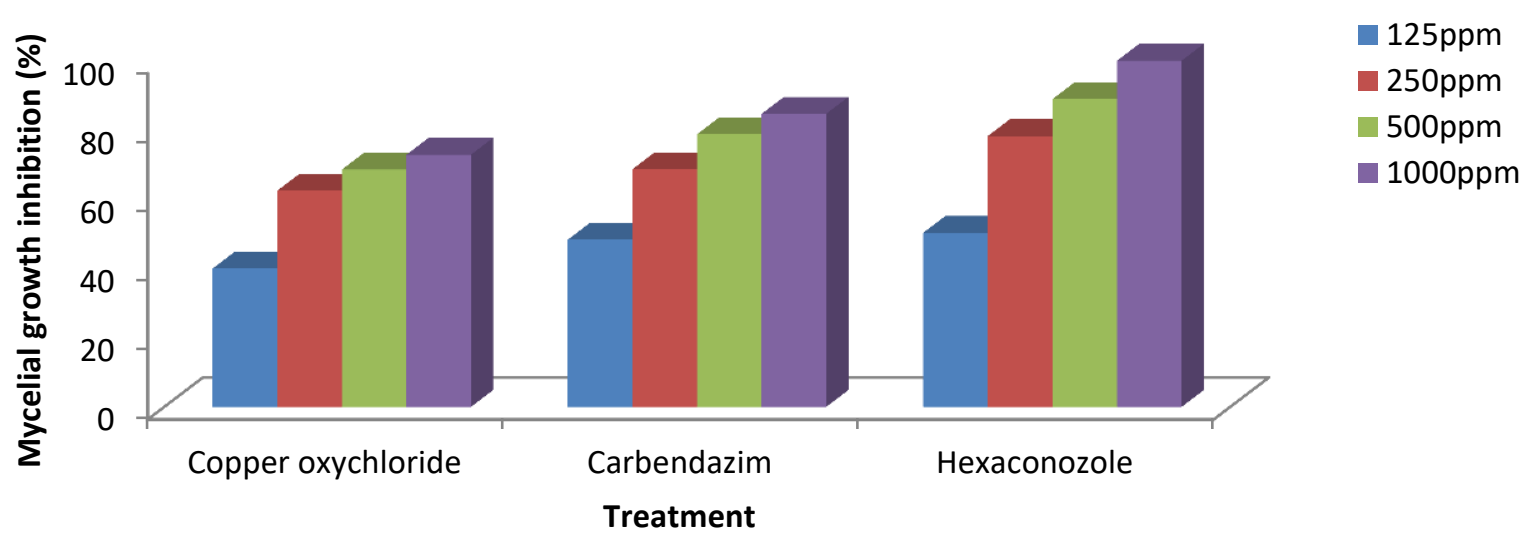

Figure 1: Effect of different concentrations of fungicides on the mycelial growth of Alternaria alternata

Table 2: Effect of different concentration of fungicides on the spore germination of Alternaria alternata

\begin{tabular}{|l|l|l|l|l|l|}
\hline \multirow{2}{*}{ Conc. } & \multicolumn{5}{c|}{ Spore germination (\%) } \\
\cline { 2 - 6 } Treatment & $125 \mathrm{ppm}$ & $250 \mathrm{ppm}$ & $500 \mathrm{ppm}$ & $1000 \mathrm{ppm}$ & Control \\
\hline Copper oxychloride & $71.60 \pm 0.20^{\mathrm{b}}$ & $57.83 \pm 0.61^{\mathrm{c}}$ & $37.15 \pm 0.30^{\mathrm{d}}$ & $18.10 \pm 0.6^{\mathrm{e}}$ & $94.73 \pm 0.24^{\mathrm{a}}$ \\
\hline Carbendazim & $69.71 \pm 0.38^{\mathrm{b}}$ & $56.73 \pm 0.68^{\mathrm{c}}$ & $34.41 \pm 0.40^{\mathrm{d}}$ & $16.15 \pm 0.58^{\mathrm{e}}$ & $94.56 \pm 0.55^{\mathrm{a}}$ \\
\hline Hexaconozole & $63.36 \pm 0.12^{\mathrm{b}}$ & $51.46 \pm 0.12^{\mathrm{c}}$ & $33.26 \pm 0.90^{\mathrm{d}}$ & $13.09 \pm 0.48^{\mathrm{e}}$ & $94.56 \pm 0.55^{\mathrm{a}}$ \\
\hline
\end{tabular}

* Each value is mean of spore germination \%age of 3 replicates \pm SD 


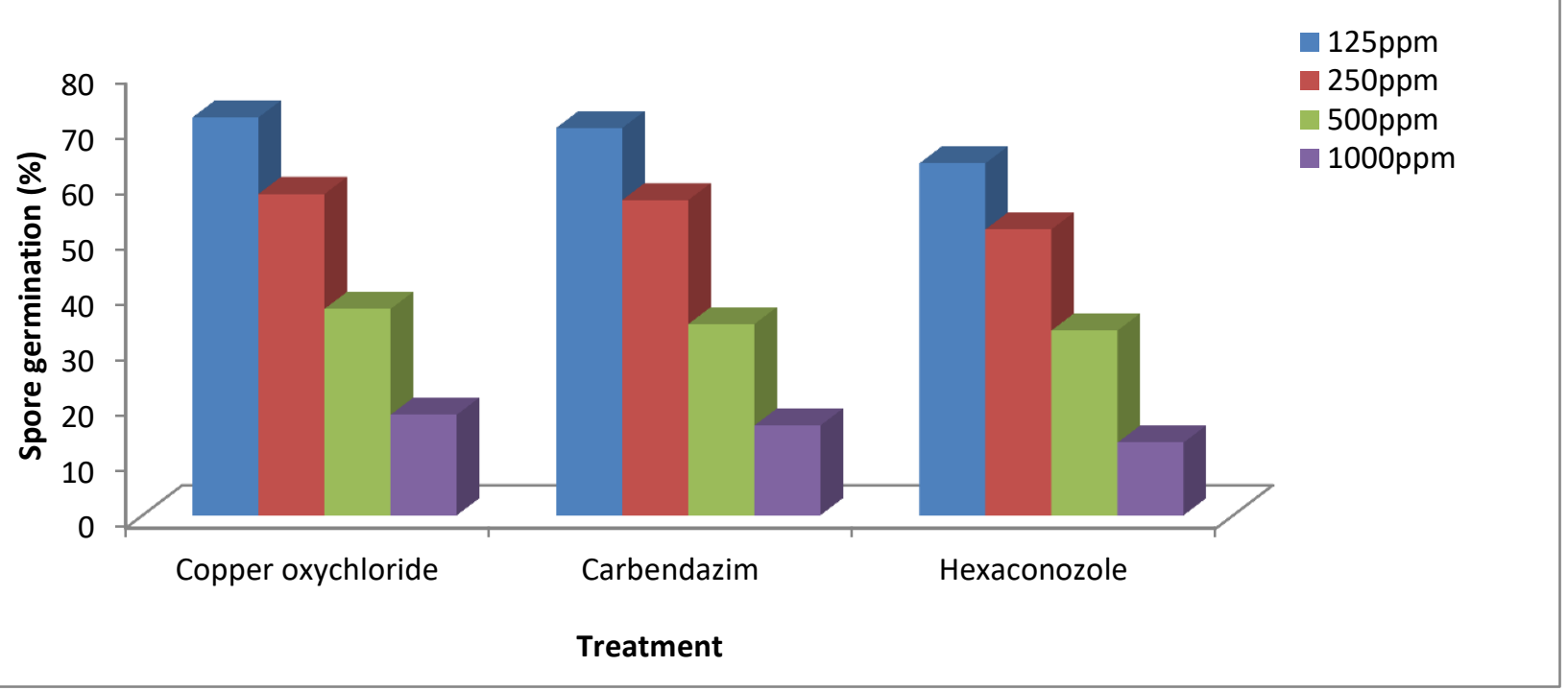

Figure 2: Effect of different concentration of fungicides on the spore germination of Alternaria alternata

\subsection{Effect of different concentration of fungicides on the mycelial growth of Mucor plumbeus}

It was revealed from the results (Table 3, Fig 3) that all the fungicides, viz. copper oxychloride, carbendazim and hexaconozole at different concentrations (1000ppm, 500 ppm, $250 \mathrm{ppm}, 125 \mathrm{ppm}$ ) brought about significant inhibition in the mycelial growth of Mucor plumbeus. However, the most effective fungicide in inhibiting the mycelial growth of Mucor plumbeus was hexaconozole $(71.92 \%)$ at highest concentration followed by carbendazim $(71.19 \%)$ and copper oxychloride $(60.04 \%)$ at the same concentration. Other concentrations also caused significant inhibition in mycelial growth but to a lesser extent. In different concentrations of hexaconozole, the inhibition in mycelial growth varies from $71.92 \%-50.82 \%$ and in different concentration of carbendazim it varies from 71.19\%-47.01\%. Likewise, the inhibition in mycelial growth in copper oxychloride ranges from $60.04 \%-42.93 \%$ in different concentrations respectively of the fungicides.
Effect of different concentrations of fungicides on the spore germination of Mucor plumbeus

It was found from the results (Table 4, Fig 4) that all the fungicides, viz. copper oxychloride, carbendazim and hexaconozole at different concentrations (1000 ppm, 500 ppm, 250ppm, 125ppm) brought about significant inhibition in the spore germination of Mucor plumbeus as compared to control. Maximum inhibition in spore germination was found in the highest concentration of the fungicide followed by lower concentration of fungicides. Amongst the fungicides, hexaconozole at highest concentration (1000ppm) was found most effective in reducing the germination of spores followed by carbendazim and copper oxychloride at same concentration. Other concentrations also brought about significant reduction in spore germination but to lesser extent. In hexaconozole the inhibition in spore germination varies from $43.51 \%-16.40 \%$ in different concentrations. In carbendazim, the reduction in spore germination varies from $69.75 \%-20.23 \%$ and in copper oxychloride it varies from $74.30 \%-23.53 \%$ respectively in different concentrations.

Table 3: Effect of different concentrations of fungicides on the mycelial growth of Mucor plumbeus

\begin{tabular}{|l|c|c|c|c|c|}
\hline \multirow{2}{*}{ Conc. } & \multicolumn{5}{|c|}{ Mycelial growth (mm) } \\
\cline { 2 - 6 } & $125 \mathrm{ppm}$ & $250 \mathrm{ppm}$ & $500 \mathrm{ppm}$ & $1000 \mathrm{ppm}$ & Control \\
\hline $\begin{array}{l}\text { Copper } \\
\text { oxychloride }\end{array}$ & $\begin{array}{c}39.80 \pm 0.60^{\mathrm{b}} \\
(42.93)\end{array}$ & $\begin{array}{c}35.14 \pm 0.05^{\mathrm{c}} \\
(49.62)\end{array}$ & $\begin{array}{c}31.99 \pm 0.08^{\mathrm{d}} \\
(54.13)\end{array}$ & $27.87 \pm 0.61^{\mathrm{e}}$ & $69.75 \pm 0.36^{\mathrm{a}}$ \\
& $36.96 \pm 0.05^{\mathrm{b}}$ & $33.23 \pm 0.30^{\mathrm{c}}$ & $29.60 \pm 0.30^{\mathrm{d}}$ & $20.09 \pm 0.36^{\mathrm{e}}$ & $69.75 \pm 0.36^{\mathrm{a}}$ \\
& $(47.01)$ & $(52.35)$ & $(57.56)$ & $(71.19)$ & \\
\hline Hexaconozole & $34.30 \pm 0.35^{\mathrm{b}}$ & $32.41 \pm 0.59^{\mathrm{c}}$ & $25.70 \pm 0.7^{\mathrm{d}}$ & $19.58 \pm 0.9^{\mathrm{e}}$ & $69.75 \pm 0.36^{\mathrm{a}}$ \\
& $(50.82)$ & $(53.53)$ & $(63.15)$ & $(71.92)$ & \\
\hline
\end{tabular}

Each value is mean of 3 replicates \pm SD $\quad$ Figures in parenthesis is the mycelial growth inhibition (\%) 


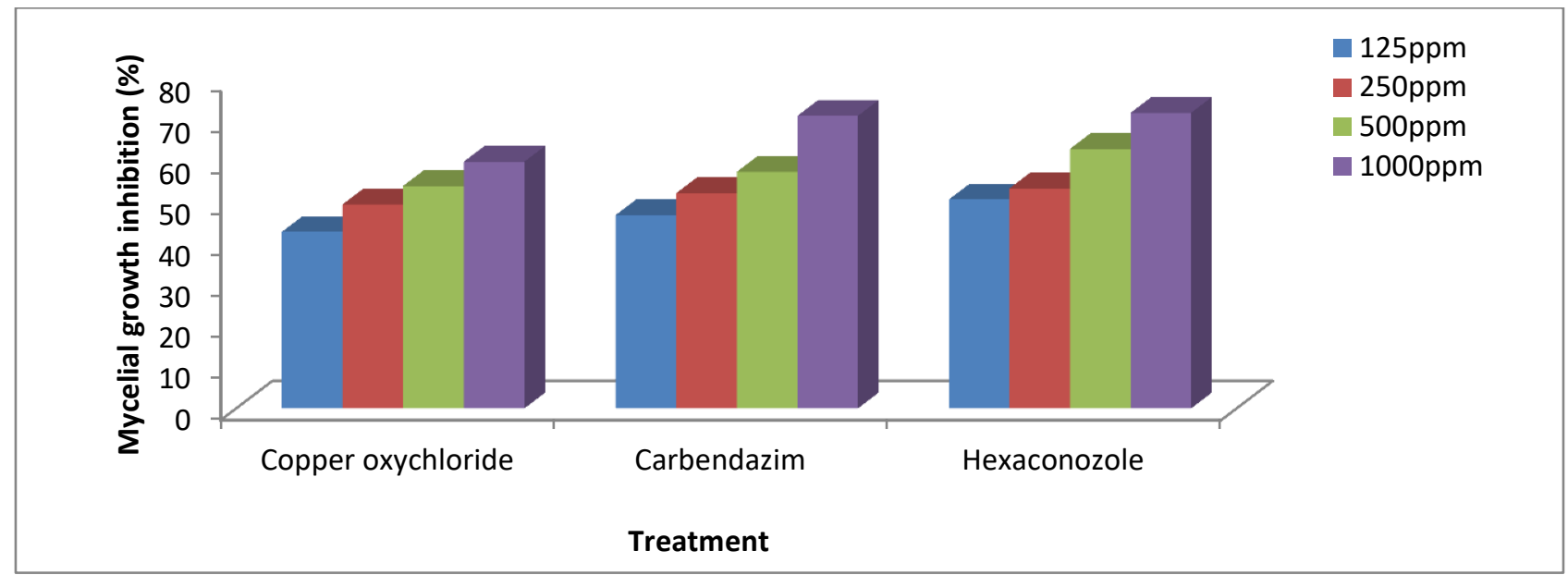

Figure 3: Effect of different concentrations of fungicides on the mycelial growth of Mucor plumbeus.

Table 4: Effect of different concentration of fungicides on the spore germination of Mucor plumbeus

\begin{tabular}{|l|l|l|l|l|l|}
\hline \multirow{2}{*}{ Treatment } & \multicolumn{5}{|c|}{ Spore germination (\%) } \\
\cline { 2 - 6 } & $125 \mathrm{ppm}$ & $250 \mathrm{ppm}$ & $500 \mathrm{ppm}$ & $1000 \mathrm{ppm}$ & Control \\
\hline Copper oxychloride & $74.30 \pm 0.20^{\mathrm{b}}$ & $56.53 \pm 0.30^{c}$ & $36.75 \pm 0.22^{\mathrm{d}}$ & $23.53 \pm 0.15^{\mathrm{e}}$ & $91.31 \pm 0.23^{\mathrm{a}}$ \\
\hline Carbendazim & $69.75 \pm 0.27^{\mathrm{b}}$ & $51.41 \pm 0.17^{\mathrm{c}}$ & $33.39 \pm 0.37^{\mathrm{d}}$ & $20.23 \pm 0.37^{\mathrm{e}}$ & $91.38 \pm 0.29^{\mathrm{a}}$ \\
\hline Hexaconozole & $43.51 \pm 0.17^{\mathrm{b}}$ & $32.63 \pm 0.45^{c}$ & $23.51 \pm 0.28^{\mathrm{d}}$ & $16.40 \pm 0.20^{\mathrm{e}}$ & $91.31 \pm 0.23^{\mathrm{a}}$ \\
\hline
\end{tabular}

* Each value represents the mean spore germination \%age of 3 replicates \pm SD

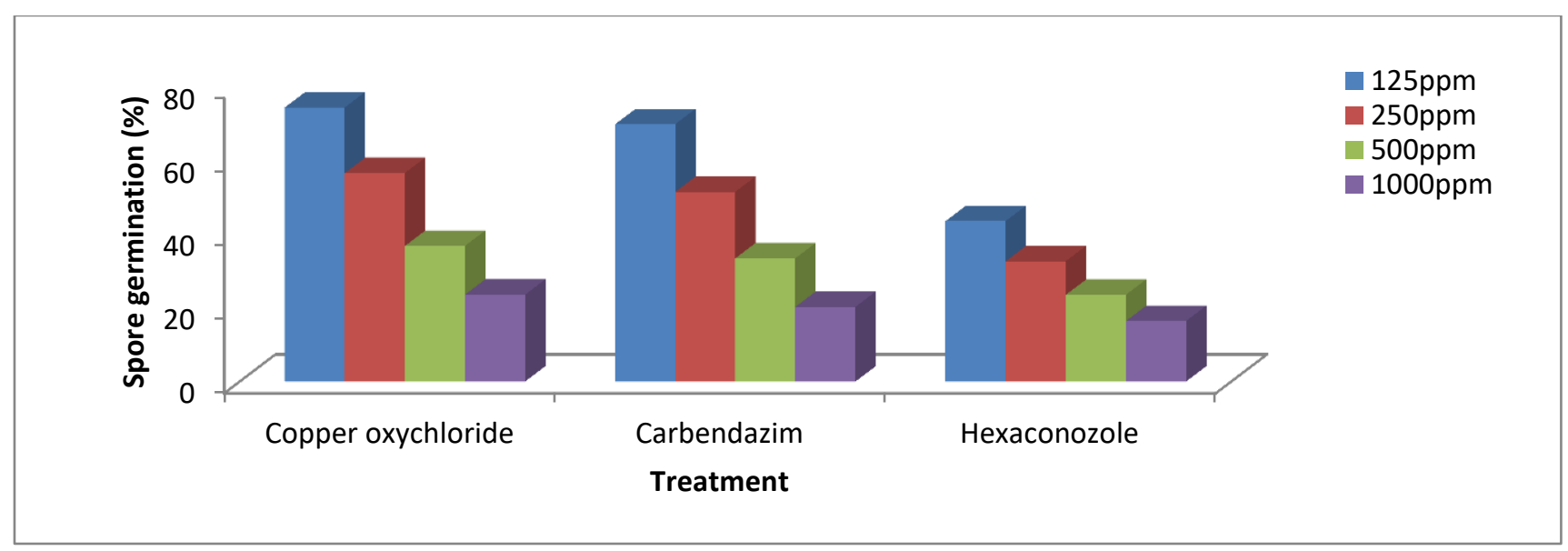

Figure 4: Effect of different concentration of fungicides on the spore germination of Mucor plumbeus

\section{DISCUSSION}

It was clear from above results that the fungus Alternaria alternata and Mucor plumbeus attacks tomato fruits in storage and causes Alternaria rot and Mucor rot of tomato fruits. Such studies on fungal rot of tomato have been carried out for the first time in Kashmir Valley. In the present study, Alternaria alternata and Mucor plumbeus were identified on the basis of symptoms caused on the infected fruits, cultural and microscopic characteristics of the fungus. Some workers also used symptomological studies, cultural and morphological and reproductive characteristics for the identification of fungus $13,14,15,16$.
In the present study some fungicides were evaluated for their antifungal activity against the fungus Alternaria alternata and Mucor plumbeus. All the concentrations of fungicides proved highly effective in reducing the mycelial growth and caused significant inhibition in the spore germination of Alternaria alternata and Mucor plumbeus. The highest concentrations of the fungicides proved more effective than lower concentrations. The efficacy of different fungicides in inhibiting the growth of rot causing fungi have been reported earlier by ${ }^{17,18}$. ${ }^{19}$ screened seven fungicides against Alternaria solani through poison food techniques and reported that Dithane M-45 is the most effective fungicide at higher concentration. ${ }^{20}$ reported that difenoconazole had a better effectiveness in vitro than Chlorothalonil in inhibition 
of mycellial growth and conidial germination of Alternaria solani and A. alternata. ${ }^{21}$ tested various chemical fungicides, systemic and non-systemic, against the mycelial growth of two fruit rot pathogens, viz. Alternaria alternata and Mucor piriformis and observed hexaconozole and carbendazim as effective. ${ }^{22}$ tested various fungicides against many vegetable rot causing fungi including $R$. stolonifer and observed carbendazim as the most effective fungicide for reducing Rhizopus rot. Some workers have studied the effect of different fungicides against different rot causing fungi of different plants $23,24,25,26,27,28$.

\section{ACKNOWLEDGEMENTS}

The authors are thankful to the Head, Department of Botany, University of Kashmir, for providing necessary facilities during the course of the study.

\section{REFERENCES}

1. Babalola DA. Makinde YO. Omonona BT. Oyekanmi MO Determinants of postharvest losses in tomato production: a case study of Imeko - Afon local government area of Ogun state. Journal of Life and Physical Science. ActaSatech. 2010. 3 (2): 14 18.

2. Snowdon AL. A colour atlas of post-harvest diseases and disorders of fruits and vegetables. Vol. 1 Wolfe scientific Ltd. London.1990.672Pp.

3. HemaMoorthy T. Prakasam V. First Report of Penicillium expansum causing bulb rot of Lilium in India. American-Eurasian J. Agric. and Environ. Sci., 2013. 13(3): 293-295.

4. Parveen S. Wani AH. In vitro efficacy of some fungicides and plant extracts on Mucor piriformes Fisher causing posthsrvest rot of peach in Kashmir valley. Trends in Biosciences, 2015. 8(3): 620-627.

5. Nwankiti AO. Kalu AD. Ene LSO. Seed yam production by minisett technique. Varietals responses to curing treatment as alternative to chemical seed dressing. Nigerian Journal of Plant Protection, 1990.13: 1-5.

6. Ellis MB. Dematiaceous Hyphomycetes. Commonwealth Mycological Institute, England. 1971. Pp 508.

7. Barnett HL. Hunter BB. Illustrated genera of Imperfect Fungi, 3rd Edition. Burgess Publishing Company. Minneapolis, Minnesota. 1972, Pp 241.

8. Watanabe T. Pictorial Atlas of Soil and Seed Fungi: morphologies of cultured fungi and key to species, 2nd ed., CRC Press, Boca Raton, Florida, USA. 2002, pp. 504.

9. Gilman JC. A Manual of Soil Fungi. Iowa State University Press, Ames. 2008, pp 382.

10. Tomkin RG. Trout SA. Pricking by entomological pins (C-Dass Gupta and Mandal: 1989), 1931.

11. Adams PB. Wong JAL. The effect of chemical pesticides on the infection of sclerotia of Sclerotinia minor by the biocontrol agent, Sporidesmium sclerotivorum. Phytopathology. 1991. 81: 13401343.

12. Kiraly Z. Klement Z. Solymosy F. Voros J. Methods in Plant Pathology with Special Reference to Breeding for Resistance. Elsevier Publishing, New York. 1974, 212.
13. Splittstoesser DF. Fruits and fruit products. pp. 101-128. In: Food and Beverage Mycology. (Ed.): L. Beuchat. Van Nostrand Reinhold, New York 1987.

14. Adaskaveg JE. Forster H. Sommer NF. Principles of post-harvest pathology and management of decays of edible horticultural crops. In: Post-harvest Technology of Horticultural Crops, (Eds.): A.A. Kader. Vol.3311. University of California Publication, California, 2002. pp. 163-195.

15. Forster H. Driever GF. Thompson DC. Adaskaveg JE. Postharvest decay management for stone fruit crops in California using the reduced risk fungicides fludioxonil and fenhexamid. 2007.Plant Dis.91:209-215.

16. Khazaeli P. Zamanizadeh H. Morid B. Bayat H. Morphological and molecular identification of Botrytis cinerea causal agent of gray mold in rose greenhouses in central regions of Iran. Int. Agr. Sci. and Res. 2010.1(1):19-24.

17. Plumbley RA. Benomyle tolerance in strain of Penicillium sclereteginum infecting yams and use of imazalid as a means of control. Tropical Agriculture Trinidad. 1985.61: 182-185.

18. Ogundana SK. Denis C. Assessment of fungicides for prevention of storage rot of yams. Pesticide Science, 1981. 11: 491-494.

19. Hawamdeh AS. Ahmad S. In vitro controle of Alternaria solani, the cause of early blight of tomato. Online journal of biological sciences. 2001. 1: 949-950.

20. Issiakhem F. Bouznad Z. In vitro evaluation of difenoconazole and Chlorothalonil on conidial germination and mycelial growth of Alternaria alternate and $A$. solani causal agent of early blight in Algeria. Twelfth Euro Blight workshop Arras (France), 2010. $14: 297-30$.

21. Parveen S. Ganie AA. Wani AH. In vitro efficacy of some fungicides on mycelial growth of Alternaria alternata and Mucor piriformis. Archives of Phytopathology and Plant Protection. 2013. 46(10): 1230-1235.

22. Parveen S. Wani AH. Bhat MY. Koka JA. Wani FA. Management of postharvest fungal rot of peach (Prunus persica) caused by Rhizopus stolonifer in Kashmir Valley, India. Plant Pathology \& Quarantine.2016. 6(1):19-29.

23. Patel, N. A., Dange, S. R. S. and Patel, S. I. (2005).Efficacy of chemicals in controlling fruit rot of tomato caused by Alternaria tomato. Indian J. Agric. Res.39: 72-75.

24. Sharma RL. Efficacy of fungicide impregnated paper liners against storage rot of tomato fruit. J.Mycol. Pl. Pathol. 2006. 26(2):310-311.

25. Banyal DK. Mankotia V. Sugha SK. Integrated management of tomato collar rot caused by Sclerotium rolfsii. J. Mycol. Pl. Pathol. 2008. 38(2):165-167.

26. Taskeen-un-Nisa..Wani AH. Mir RA. Fusarium rot of tomato and its management in Kashmir. J. Pl. Dis. Sci.2011. 6(2): 107-113.

27. Parveen S. Wani AH. Bhat MY. Malik. AR. Koka JA. Ashraf N. Antimycotic potential of some phytoextracts on some pathogenic fungi. J. Biopest. 2017. 10 (1): 60-65.

28. Koka JA. Bhat MY. Wani AH. Malik AR. Wani TA. Parveen S. Management of postharvest fungal rot of tomato (Lycopersicon esculentum) in Kashmir Valley, India. International Journal of Advance Research in Science and Engineering. 2018. 07(4):1967-1976. 